\title{
Implementasi Data Mining dengan Metode Algoritma Apriori dalam Menentukan Pola Pembelian Obat
}

\author{
Robi Yanto*1, Riri Khoiriah ${ }^{2}$ \\ ${ }^{1,2}$ Sistem Informasi STMIK Bina Nusantara Jaya Lubuklingau \\ E-mail: ${ }^{* 1}$ wrtech2009@yahoo.co.id, ${ }^{2}$ khoiriahriri12@yahoo.co.id
}

\begin{abstract}
Abstrak
Data mining merupakan proses untuk mendapatkan informasi yang berguna dari gudang basis data yang berupa ilmu pengetahuan. penelitian ini melakukan analisa data dengan menggunakan data mining dan metode algoritma appriori. Sistem yang dibangun ditujukan untuk pemenuhan dalam penentuan pola pembelian obat dengan menggunakan bahasa pemrograman Visual Basic 6.0 dan database Mysql pada studi kasus di sektor kesehatan. Sistem ini dibangun berdasarkan kebutuhan pengguna yang diperoleh melalui metode wawancara dan studi lapangan. Metodelogi pengembangan sistem yang digunakan yaitu metode waterfall yang terdiri Analisis, Desain, Pengkodean dan Pengujian. Hasil pengujian dengan algoritma apriori dan sistem yang dibangun menunjukan hasil yang telah memenuhi kebutuhan dalam penentuan pola pembelian obat berdasarkan kecenderungan pembelian obat oleh pelanggan. Dibandingkan dengan sistem yang sedang berjalan kinerja tersebut ditunjukan pada efektifitas informasi dari sistem tentang penentuan pola pembelian obat untuk ketersediaan obat dan tata letak obat untuk memudahkan dalam mengetahui keberadaan obat yang dilihat dari 2 itemset obat.
\end{abstract}

Kata Kunci - Data Mining, Appriori, Association Rules, Itemset, Pembelian

\begin{abstract}
Data mining is the process to obtain useful information from the warehouse database in the form of science. This study analyzes the data by using data mining algorithms and methods appriori. The system is built is intended for fulfillment in determining the pattern of drug purchases by using Visual Basic 6.0 programming language and MySQL database on a case study in the health sector. The system is built based on the needs of users obtained through interviews and field studies. System development methodology used is the waterfall method which consists Analysis, Design, Coding and Testing. Test results with a priori algorithms and systems built show results that have met the requirements in determining the pattern of drug purchases by the tendency of drug purchases by customers. Compared with the current system performance information is shown on the effectiveness of the system of determining the pattern of drug purchases for the availability of drugs and drug layout for ease in knowing where drugs are viewed from 2 itemset drug.
\end{abstract}

Keywords — Data Mining, Appriori, Association Rules, Itemset, Purchasing

\section{PENDAHULUAN}

Data Mining adalah proses ekstraksi informasi dari kumpulan data melalui penggunaan algoritma dan teknik yang melibatkan bidang ilmu statistik, mesin pembelajaran, dan sistem manajemen database [1]. Data Mining digunakan untuk ekstraksi informasi penting yang tersembunyi dari dataset yang besar. Dengan adanya data mining maka akan didapatkan suatu permata berupa pengetahuan di dalam kumpulan data - data yang banyak jumlahnya. 
Salah satu area penerapan data mining adalah di dalam bidang kesehatan. Bila sasaran pembelian obat tidak ditentukan secara baik, dalam arti tidak diupayakan mencari sasaran pembelian obat yang potensial, maka hanya akan menghabiskan banyak waktu dan biaya yang seharusnya bisa diminimalisir melalui pemilihan target pembelian obat yang baik. Salah satu cara yang dapat diterapkan adalah dengan menerapkan penggunaan data mining.

Algoritma apriori adalah algoritma pengambilan data dengan aturan asosiatif (Association rule) untuk menentukan hubungan asosiatif suatu kombinasi item [2]. Association Rule yang dimaksud dilakukan melalui mekanisme penghitungan support dan confidence dari suatu hubungan item. Sebuah rule asosiasi dikatakan interesting jika nilai support adalah lebih besar dari minimum support dan juga nilai confidence adalah lebih besar dari minimum confidence. Algoritma apriori ini akan cocok untuk diterapkan bila terdapat beberapa hubungan item yang ingin dianalisa. Salah satunya yang bisa diterapkan adalah di dalam bidang kesehatan dan penentuan pola pembelian obat

Dalam persaingan di dunia bisnis, khususnya industri Apotek, menuntut para pengembang untuk menemukan suatu strategi jitu yang dapat meningkatkan penjualan obat. Salah satu cara mengatasinya adalah dengan tetap tersediaannya berbagai jenis obat yang dibutuhkan oleh konsumen. Untuk mengetahui obat apa saja yang biasa dibeli oleh konsumen. Penerapan Algoritma Apriori dapat membantu dalam membentuk kandidat kombinasi item, kemudian dilakukan pengujian apakah kombinasi tersebut memenuhi parameter support dan confidence minimum yang merupakan nilai ambang yang diberikan oleh pengguna. Jika memenuhi parameter support dan confidence maka hasil tersebut dapat membantu dalam penentuan pola pembelian obat dan membantu tata letak obat berdasarkan kencenderungan konsumen membeli obat.

Ruang lingkup penelitian ini sebagai dasar batasan penelitian adalah menggunakan metode algoritma appriori, pengujian dilakukan berdasarkan nama obat bukan taksonomi obat, kombinasi 2 itemset yang akan dijadikan tolok ukur dalam pencarian nilai support dan confidence pada data transaksi pembelian obat, pengolahan data dilakukan terhadap data penjualan obat pada periode Januari dan februari 2014 dengan sampel 20 data transaksi. Dengan dilakukannya penelitian ini diharapkan dapat memberikan hasil berupa informasi yang dapat bermanfaat bagi pihak -pihak terkait dalam melakukan pengambilan keputusan manajerial, terutama dalam penentuan pola pembelian obat dan juga dapat membantu dalam tata letak obat.

\section{METODE PENELITIAN}

\subsection{Analisis Penelitian Terkait}

Gunadi G \& Sensuse D [8] melakukan penelitian menggunakan metode data mining dengan algoritma appriori dan FP Growth dalam menentukan strategi penjualan dan pemasaran yang efektif pada PT gramedia. Dimana algoritma appriori dan FP Growth adalah algoritma yang digunakan untuk membantu menemukan sejumlah aturan asosiasi dari basis data transaksi penjualan produk buku. Pada aturan asosiasi algortima FP growth menemukan hubungan antara itemset dengan tingkat kekuatan aturan asosiasi support dan confidence sebesar 0,273 sedangkan pada aturan asosiasi algoritma Appriori menemukan hubungan antar itemset dengan tingkat kekuatan aturan asosiasi support dan confidence sebesar 0,725. Sehingga disimpulkan bahwa dengan algoritma appriori dapat membantu dalam menentukan strategi penjualan dan pemasaran buku.

\subsection{Analisis Permasalahan}

Pada gambar 2 tahapan awal yang dilakukan adalah melakukan analisa terhadap data yang akan diolah berdasarkan hasil studi lapangan. Pada data penjualan obat selama disimpan dalam aplikasi Microsoft Excel sehingga data penjualan yang semakin hari semakin banyak tersebut hanya berfungsi sebagai arsip dan laporan penjualan obat bagi perusahaan dan tidak dapat 
dimanfaatkan perusahaan untuk pengembangan dalam penentuan pola pembelian obat. Oleh sebab itu perusahaan Apotik Musi Rawas memerlukan sistem yang mampu memberikan ilmu pengetahuan yang mampu membantuk level manajerial dalam mengambil keputusan khusunya dalam penyediaan obat yang efektif dan efisien dari penentuan pola pembelian obat, sehingga obat yang paling sering dibeli tersebut dapat menjadi acuan untuk mengembangkan strategi dalam pola penentuan pembelian obat.

\subsection{Kerangka Kerja Penelitian}

Metodologi penelitian dilakukan dengan mengumpulkan data. Proses pengumpulan data dilakukan dengan dua cara yaitu: studi kepustakaan dan studi lapangan. Studi kepustakaan dilakukan untuk memahami penerapan data mining seperti mengumpulkan teori-teori yang berhubungan dengan data mining dan studi lapangan dilakukan mendapatkan data penelitian. Data yang diperoleh akan dianalisa untuk mengetahui kebutuhan dalam proses Asosiasi data dalam penyelesaian masalah. Pada gambar 1 menunjukan kerangka kerja penelitian.

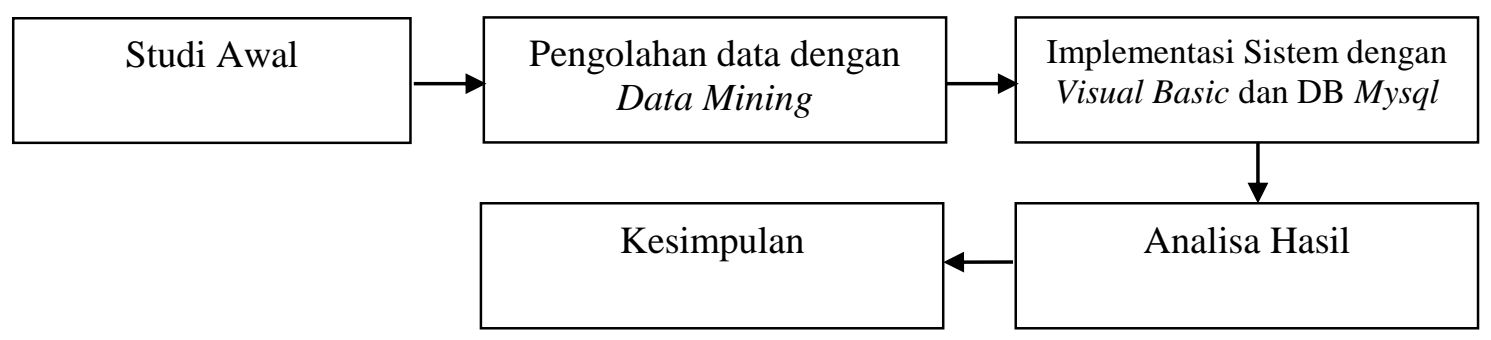

Gambar 1. Metodelogi Penelitian

\subsubsection{Studi Awal}

Tahap ini bertujuan dalam merumuskan latar belakang, tujuan dan permasalahan yang akan dibahas adapun beberapa hal yang dilakukan pada tahapan ini adalah:
a. Mempelajari masalah
b. Menentukan ruang lingkup masalah
c. Mempelajari beberapa literatur
d. Analisa Data

\subsubsection{Pengelolaan Data dengan Data Mining}

Pada tahap pengolahan data terlebih dahulu melakukan identifikasi masalah yang ada dan sering dihadapi oleh pihak Apotek, untuk kemudian mendeskripsikan masalah-masalah tersebut untuk diperoleh solusinya. Tahap selanjutnya dilakukan analisa masalah menggunakan teknik data mining dengan algoritma Apriori untuk mendapatkan hasil sebagai tujuan yang akan dicapai.

\subsubsection{Implementasi Sistem}

Implementasi Pada tahap ini untuk memudahkan dalam pembuktian hasil analisa yang dilakukan, dibutuhkan sistem yang akan dibangun menggunakan bahasa pemrograman visual basic 6.0 dan database mysql. 


\subsubsection{Analisis Hasil}

Pada tahap ini dilakukan analisis hasil berdasarkan perhitungan algoritma appriori dan analisis hasil dari sistem yang dibangun sehingga menghasilkan keputusan yang dapat digunakan untuk pengambilan keputusan dalam penentuan pola pembelian obat. Adapun langkah analisa hasil yang dilakukan adalah:

a. Mengolah data transaksi penjualan obat untuk diuji dengan menggunakan metode data mining

b. Mengolah data transaksi penjualan obat dengan sistem yang dibangun

c. Melakukan perbandingan dari hasil pengujian dari data mining dan sistem yang dibangun apakah hasil dari pengujian tersebut sudah sesuai. jika sudah sesuai maka dapat dijadikan pedoman dalam pengambilan keputusan dalam penentuan pola pembelian obat.

\subsection{Metode Data Mining}

Analisis asosiasi atau association rule mining adalah teknik data mining untuk menemukan aturan asosiasi antara suatu kombinasi item [4]. Interestingness measure yang dapat digunakan dalam data mining adalah:

a. Support, adalah suatu ukuran yang menunjukkan seberapa besar tingkat dominasi suatu item atau itemset dari keseluruhan transaksi.

b. Confidence, adalah suatu ukuran yang menunjukkan hubungan antar dua item secara conditional (berdasarkan suatu kondisi tertentu).

\subsection{Algoritma Apriori}

Algoritma apriori adalah algoritma pengambilan data dengan aturan asosiatif (Association rule) untuk menentukan hubungan asosiatif suatu kombinasi item [3].

\subsubsection{Analisis Pola Frekuensi Tinggi dengan Algoritma Appriori}

Mencari kombinasi item yang memenuhi syarat minimum dari nilai support dalam basis data. Nilai support sebuah item diperoleh dengan menggunakan rumus berikut:

$$
\operatorname{Support}(\mathrm{A})=\frac{\text { Jumlah transaksi mengandung } \mathrm{A}}{\text { Total Transaksi }}
$$

Nilai support dari 2 item diperoleh dengan menggunakan rumus:

$$
\begin{array}{r}
\text { Support }(A, B)=P(A \cap B) \\
\text { Support }(\mathrm{A}, \mathrm{B})=\frac{\sum \text { transaksi mengandung A dan B }}{\sum \text { transaksi }}
\end{array}
$$

\subsubsection{Pembentukan Aturan Asosiasi}

Setelah semua pola frekuensi tinggi ditemukan, barulah dicari aturan asosiasi yang memenuhi syarat minimum untuk confidence dengan menghitung confidence aturan asosiatif $\mathrm{A}$ U B. Nilai confidence dari aturan A U B diperoleh dengan rumus berikut.

$$
\text { Confidence }=P(B \mid A)=\frac{\sum \text { transaksi mengandung A dan } \mathrm{B}}{\sum \text { Transaks mengandung } \mathrm{A}}
$$

Untuk menentukan aturan asosiasi yang akan dipilih maka harus diurutkan berdasarkan Support $\times$ Confidence. Aturan diambil sebanyak $n$ aturan yang memiliki hasil terbesar [7]. 


\subsection{Implementasi Algoritma Apriori}

Untuk melakukan proses pengolahan data transaksi obat maka perlu digambarkan tahapan kerja yang dapat dilakukan pada algoritma apriori seperti gambar 3 berikut.

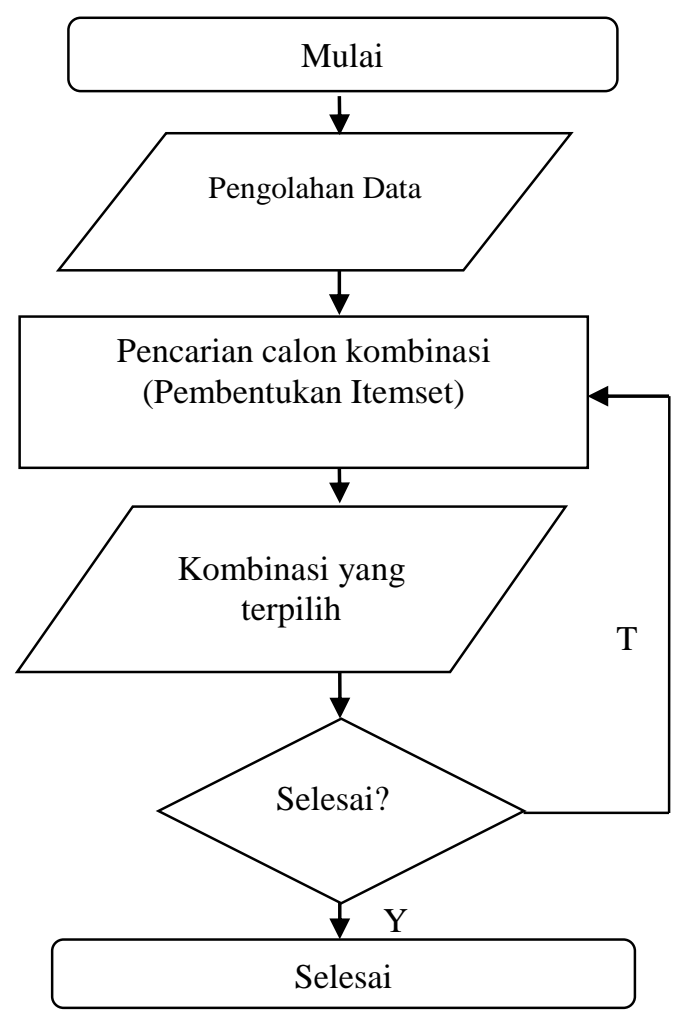

Gambar 2. Flowchart Algoritma Apriori

\subsection{Data Transaksi Penjualan Obat}

Berdasarkan data transaksi pada periode Januari dan Februari 2014 dilakukan akumulasi transaksi penjualan obat dapat dilihat pada tabel 1 .

Tabel 1. Pola Transaksi Penjualan Obat

\begin{tabular}{|c|l|}
\hline Transaksi & \multicolumn{1}{c|}{ Item pembelian } \\
\hline 1 & Kaditic, Asamefenamat, Amoxicilin, Redoxon, Sangobion \\
\hline 2 & Sanmol, Cefadroxil, CDR,Redoxon \\
\hline 3 & Amoxicilin, Asamefenamat, CDR, Cefadroxil, Nonflamin \\
\hline 4 & Asamefenamat, Nonflamin, Amoxicilin \\
\hline 5 & Sanmol, Asamefenamat, Redoxon, Amoxicilin \\
\hline 6 & Cefadroxil, Sanmol, CDR, Anastan \\
\hline 7 & Anastan, Amoxicilin, Redoxon \\
\hline 8 & Kaditic, Asamefenamat, Nonflamin, CDR \\
\hline 9 & Cefadroxil, Sanmol, CDR, Redoxon \\
\hline 10 & Amoxicilin, Nonflamin, Asamefenamat \\
\hline 11 & Asamefenamat, Kaditic, CDR, Cefadroxil, Nonflamin \\
\hline 12 & Sanmol, CDR, Cefadroxil, Redoxon \\
\hline 13 & Sanmol, Amoxicilin, Cefadroxil, Asamefenamat \\
\hline 14 & Kaditic, Asamefenamat, Amoxicilin, Anastan, CDR \\
\hline 15 & Sanmol, Cefadroxil, Asamefenamat, Redoxon \\
\hline
\end{tabular}


Citec Journal, Vol. 2, No. 2, Februari 2015 - April 2015

Tabel 1. (lanjutan)

\begin{tabular}{|c|l|}
\hline Transaksi & \multicolumn{1}{c|}{ Item pembelian } \\
\hline 16 & Asamefenamat, Amoxicilin, CDR, metronidazol \\
\hline 17 & Anastan, Amoxicilin, Nonflamin, Kaditik \\
\hline 18 & Nonflamin, Asamefenamat, CDR, Amoxicilin, Kaditic \\
\hline 19 & Redoxon, Sanmol, Cefadroxil \\
\hline 20 & Kaditic, Amoxicilin, CDR, Redoxon \\
\hline
\end{tabular}

\subsection{Tabulasi Data Transaksi}

Pada data transaksi penjualan obat di bentuk tabel tabular yang akan mempermudah dalam mengetahui berapa banyak item yang ada dibeli dalam setiap transaksi seperti pada tabel 2 berikut:

Tabel 2. Format Tabular Data Transaksi

\begin{tabular}{|c|c|c|c|c|c|c|c|c|c|c|c|}
\hline $\begin{array}{c}\text { Tran- } \\
\text { saksi }\end{array}$ & $\begin{array}{c}\text { Amoxi- } \\
\text { Cilin }\end{array}$ & $\begin{array}{c}\text { Anas- } \\
\text { tan }\end{array}$ & $\begin{array}{c}\text { Asame } \\
\text { fenama } \\
\mathrm{t}\end{array}$ & CDR & $\begin{array}{c}\text { Cefad- } \\
\text { roxil }\end{array}$ & $\begin{array}{c}\text { Kad- } \\
\text { itic }\end{array}$ & $\begin{array}{c}\text { Nonfl- } \\
\text { amin }\end{array}$ & $\begin{array}{c}\text { Redo- } \\
\text { xon }\end{array}$ & $\begin{array}{c}\text { San- } \\
\text { mol }\end{array}$ & $\begin{array}{c}\text { Sango- } \\
\text { bion }\end{array}$ & $\begin{array}{c}\text { Metron } \\
\text { i-dazol }\end{array}$ \\
\hline 1 & 1 & 0 & 1 & 0 & 0 & 1 & 0 & 1 & 0 & 1 & 0 \\
\hline 2 & 0 & 0 & 0 & 1 & 1 & 0 & 0 & 1 & 1 & 0 & 0 \\
\hline 3 & 1 & 0 & 1 & 1 & 1 & 0 & 1 & 0 & 0 & 0 & 0 \\
\hline 4 & 1 & 0 & 1 & 0 & 0 & 0 & 1 & 0 & 0 & 0 & 0 \\
\hline 5 & 1 & 0 & 1 & 0 & 0 & 0 & 0 & 1 & 1 & 0 & 0 \\
\hline 6 & 0 & 1 & 0 & 1 & 1 & 0 & 0 & 0 & 1 & 0 & 0 \\
\hline 7 & 1 & 1 & 0 & 0 & 0 & 0 & 0 & 1 & 0 & 0 & 0 \\
\hline 8 & 0 & 0 & 1 & 1 & 0 & 1 & 1 & 0 & 0 & 0 & 0 \\
\hline 9 & 0 & 0 & 0 & 1 & 1 & 0 & 0 & 1 & 1 & 0 & 0 \\
\hline 10 & 1 & 0 & 0 & 0 & 0 & 0 & 1 & 0 & 0 & 0 & 0 \\
\hline 11 & 0 & 0 & 1 & 1 & 1 & 1 & 1 & 0 & 0 & 0 & 0 \\
\hline 12 & 0 & 0 & 0 & 1 & 1 & 0 & 0 & 1 & 1 & 0 & 0 \\
\hline 13 & 1 & 0 & 1 & 0 & 1 & 0 & 0 & 0 & 1 & 0 & 0 \\
\hline 14 & 1 & 1 & 1 & 1 & 0 & 1 & 0 & 0 & 0 & 0 & 0 \\
\hline 15 & 0 & 0 & 1 & 0 & 1 & 0 & 0 & 1 & 1 & 0 & 0 \\
\hline 16 & 1 & 0 & 1 & 1 & 0 & 0 & 0 & 0 & 0 & 0 & 1 \\
\hline 17 & 1 & 1 & 0 & 0 & 0 & 1 & 1 & 0 & 0 & 0 & 0 \\
\hline 18 & 1 & 0 & 1 & 1 & 0 & 1 & 1 & 0 & 0 & 0 & 0 \\
\hline 19 & 0 & 0 & 0 & 0 & 1 & 0 & 0 & 1 & 1 & 0 & 0 \\
\hline 20 & 1 & 0 & 0 & 1 & 0 & 1 & 0 & 1 & 0 & 0 & 0 \\
\hline Jumlah & 12 & 4 & 12 & 11 & 9 & 7 & 7 & 9 & 8 & 1 & 1 \\
\hline
\end{tabular}

\subsection{Pembentukan Itemset}

\subsubsection{Itemset}

Berikut ini adalah penyelesaian berdasarkan data yang sudah disediakan pada tabel 2 Proses pembentukan $C_{1}$ atau disebut dengan 1 itemset dengan jumlah minimum support $=40 \%$ Dengan rumus sebagai berikut:

$$
\text { Support }(A)=\frac{\text { Jumlah transaksi mengandung A }}{\text { Total Transaksi }}
$$


Tabel 3. Support dari setiap Item

\begin{tabular}{|l|r|r|}
\hline Name Item & Jumlah & Support \\
\hline Amoxcilin & 12 & $\mathbf{6 0 \%}$ \\
\hline Anastan & 4 & $20 \%$ \\
\hline Asamefenamat & 12 & $\mathbf{6 0 \%}$ \\
\hline CDR & 11 & $\mathbf{5 5 \%}$ \\
\hline Cefadroxil & 9 & $\mathbf{4 5 \%}$ \\
\hline Kaditic & 7 & $35 \%$ \\
\hline Nonflamin & 7 & $35 \%$ \\
\hline Redoxon & 9 & $\mathbf{4 5 \%}$ \\
\hline Sanmol & 8 & $\mathbf{4 0 \%}$ \\
\hline Sangobion & 1 & $5 \%$ \\
\hline Metronidazol & 1 & $5 \%$ \\
\hline
\end{tabular}

Dari proses pembentukan itemset pada tabel 3 dengan minimum support $40 \%$ dapat diketahui yang memenuhi standar minimum support yaitu pada obat amoxcilin, asamefenamat, CDR, cefadroxil, redoxon dan sanmol. Kemudian dari hasil pembentukan 1 itemset akan dilakukan kombinasi 2 itemset seperti pada tabel 4.

\subsubsection{Kombinasi 2 Itemset}

Proses pembentukan $\mathrm{C}_{2}$ atau disebut dengan 2 itemset dengan jumlah minimum support $=40 \%$ Dapat diselesaikan dengan rumus berikut:

$$
\begin{aligned}
& \text { Support }(\mathrm{A}, \mathrm{B})=\mathrm{P}(\mathrm{A} \cap \mathrm{B}) \\
& \text { Support }(\mathrm{A}, \mathrm{B}) \\
& \text { Support }(\mathrm{A}, \mathrm{B})=\frac{\sum \text { transaksi mengandung } \mathrm{A} \text { dan } \mathrm{B}}{\sum \text { transaksi }}
\end{aligned}
$$

Tabel 4. Minimum Support dari 2 Itemset $40 \%$

\begin{tabular}{|l|r|r|}
\hline Nama Item & Jumlah & Support \\
\hline Amoxilin, Asamefenamat & 10 & $\mathbf{5 0 \%}$ \\
\hline Amoxilin,CDR & 6 & $30 \%$ \\
\hline Amoxilin,Cefadroxil & 2 & $10 \%$ \\
\hline Amoxcilin,Redoxon & 4 & $20 \%$ \\
\hline Amoxcilin,sanmol & 2 & $10 \%$ \\
\hline asanefenamat,CDR & 6 & $30 \%$ \\
\hline Asamefenamat,Cefadroxil & 3 & $15 \%$ \\
\hline Asamefenamat,Redoxon & 3 & $15 \%$ \\
\hline Asamefenamat,Sanmol & 3 & $15 \%$ \\
\hline CDR,Cefadroxil & 6 & $30 \%$ \\
\hline CDR, Redoxon & 4 & $20 \%$ \\
\hline CDR,Sanmol & 4 & $20 \%$ \\
\hline Cefadroxil,Redoxon & 4 & $20 \%$ \\
\hline Cefadroxil,Sanmol & 10 & $\mathbf{5 0 \%}$ \\
\hline Redoxon,Sanmol & 6 & $30 \%$ \\
\hline
\end{tabular}


Dari kombinasi 2 itemset dengan minimum support $40 \%$ dapat diketahui kombinasi 2 itemset yang memenuhi standar minimum support yaitu amoxcilin, asamefenamat dengan support sebesar $50 \%$ dan cefadroxil, sanmol dengan support $50 \%$. Dari hasil kombinasi 2 itemset akan dilakukan pembentukan 3 itemset seperti pada tabel 5.

\subsubsection{Kombinasi 3 itemset}

Proses pembentukan $\mathrm{C}_{3}$ atau disebut dengan 3 itemset dengan jumlah minimum support $=40 \%$ Dapat diselesaikan dengan rumus berikut:

$$
\text { Support }(\mathrm{A}, \mathrm{B})=\frac{\sum \text { transaksi mengandung } \mathrm{A}, \mathrm{B}, \text { dan } \mathrm{C}}{\sum \text { transaksi }}
$$

Tabel 5. Kombinasi 3 Itemset

\begin{tabular}{|l|c|c|}
\hline Nama Item & Jumlah & Support \\
\hline amoxcilin,asamefenamat,cefadroxil & 2 & $10 \%$ \\
\hline amoxilin,asamefenamat, sanmol & 2 & $10 \%$ \\
\hline amoxilin,cefadroxil,sanmol & 1 & $5 \%$ \\
\hline asamfenamat,cefadroxil,sanmol & 1 & $5 \%$ \\
\hline
\end{tabular}

Karena Kombinasi 3 itemset tidak ada yang memenuhi minimal support $40 \%$, maka kombinasi 2 itemset yang memenuhi untuk pembentukan asosiasi.

\subsection{Pembentukan Aturan Asosiasi}

Setelah semua pola frekuensi tinggi ditemukan, barulah dicari aturan asosiasi yang memenuhi syarat minimum untuk confidence dengan menghitung confidence aturan asosiatif $\mathrm{A} \rightarrow \mathrm{B}$.

Minimum Confidence $=70 \%$

Nilai Confidence dari aturan $\mathrm{A} \rightarrow \mathrm{B}$ diperoleh

$$
\text { confidence }=P(B \mid A)=\frac{\sum \text { transaksi mengandung A dan B }}{\sum \text { Transaks mengandung A }}
$$

Tabel 6. Aturan Asosiasi

\begin{tabular}{|l|l|l|}
\hline Aturan & \multicolumn{2}{|l|}{ Confidence } \\
\hline $\begin{array}{l}\text { Jika membeli amoxcilin maka membeli } \\
\text { asamefenamat }\end{array}$ & $9 / 12$ & $75 \%$ \\
\hline $\begin{array}{l}\text { Jika membeli cefadroxil maka membeli } \\
\text { sanmol }\end{array}$ & $7 / 9$ & $77.77 \%$ \\
\hline
\end{tabular}

Berdasarkan Tabel 6, obat yang paling sering dibeli oleh konsumen adalah Cefadroxil, sanmol, amoxcilin dan asamefenamat, dengan diketahuinya obat yang paling sering dibeli konsumen, maka perusahaan dapat menyusun strategi dalam penentuan pembelian obat untuk menjaga ketersedian obat yang dibutuhkan konsumen dan juga dapat mengatur tata letak obat berdasarkan kombinasi itemset obat yang terbentuk. 
2.11. Perancangan (Design)

\subsubsection{Diagram Konteks}

Diagram konteks atau disebut juga dengan model sistem fundamental merepresentasikan seluruh elemen sistem sebagai sebuah bubble tunggal dengan data input dan output yang ditunjukkan oleh anak panah yang masuk dan keluar secara bertahap [6]. Berdasarkan hasil analisis, maka diagram konteks dari simulasi aplikasi penerapan data mining penjualan dapat dilihat pada gambar 4 .

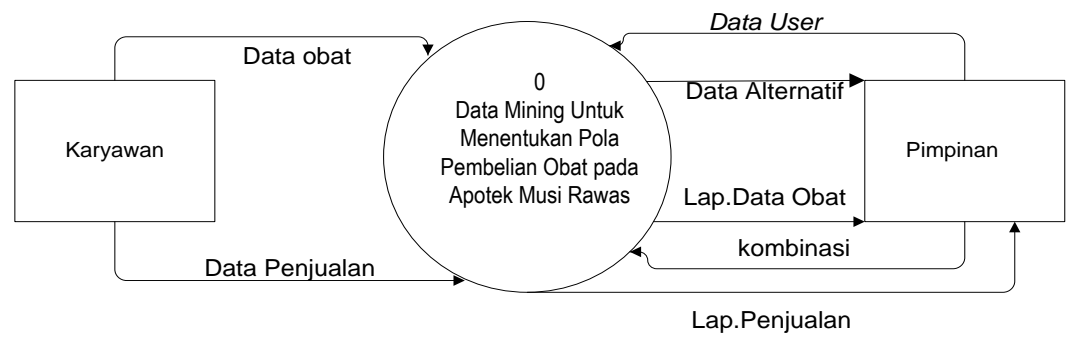

Gambar 3. Diagram Konteks

Dari proses analisa yang telah dilakukan, maka digambarkan rancangan sistem yang akan dibagun bertujuan untuk membentuk kerangka aplikasi yang melibatkan karyawan dan pimpinan dalam proses menentukan pola pembelian obat. Dalam proses ini akan dijabarkan secara detail pada diagram level 0.

\subsubsection{Diagram Level 0}

Pada proses ini dapat diketahui gambaran sistem akan bekerja dalam penentuan pola pembelian obat yaitu melalui proses pengolahan data penjualan obat untuk diakumulasi jumlah obat dalam bentuk tabular yang kemudian dilakukan proses kombinasi itemset obat. Setelah mendapatkan frequent itemset pada obat baru dilakukan perhitungan untuk mengetahui tingkat support dan confidence dari kombinasi itemset obat yang terpilih dari hasil tersebut dijadikan acuan dalam pola pembelian obat serta juga dapat dilakukan untuk menentukan tata letak obat berdasarkan kecenderungan obat yang dibeli. 
Citec Journal, Vol. 2, No. 2, Februari 2015 - April 2015

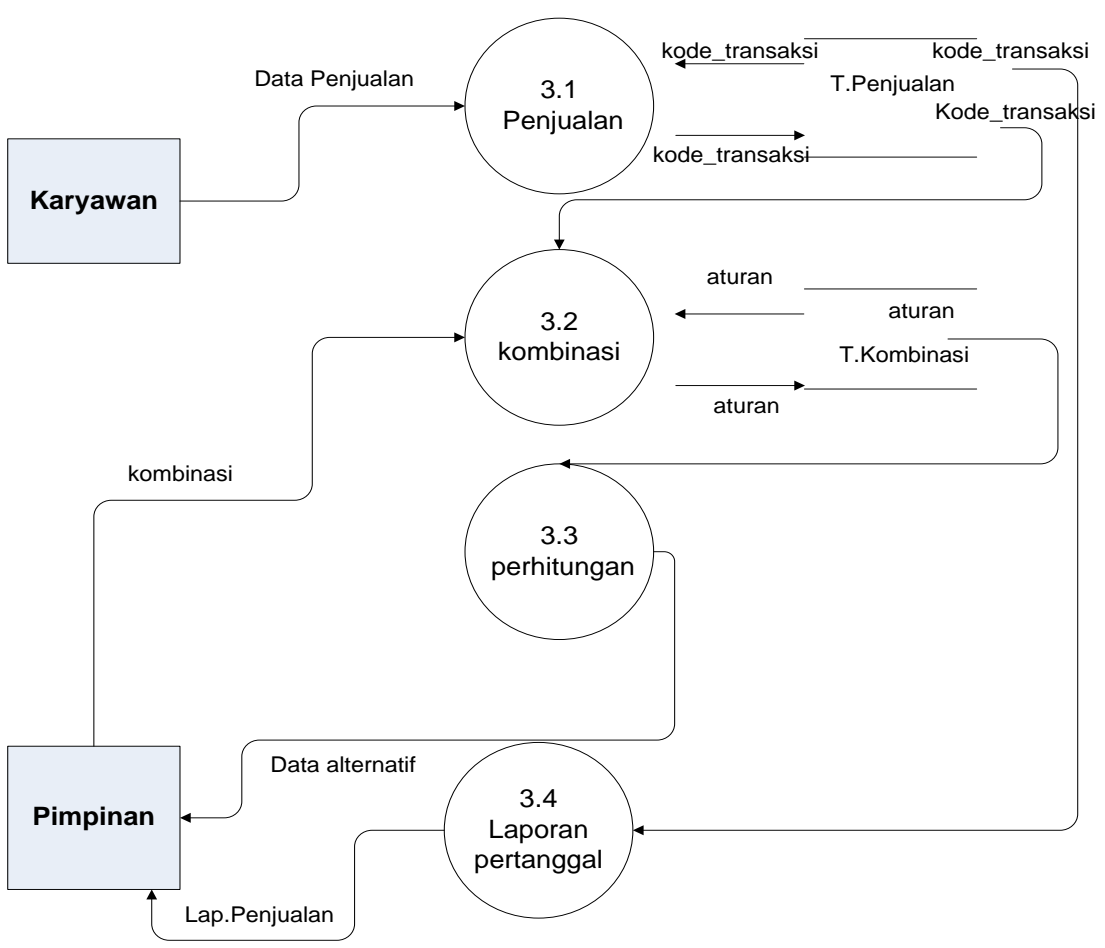

Gambar 4. Diagram Level 0

\subsection{Implementasi Sistem}

Dari hasil perancangan data flow diagram dapat dibangun rancangan sistem sesuai dengan algoritma appriori. dari data transaksi penjualan obat dapat dilakukan aturan assosiasi. Dilihat pada gambar 6. Sebanyak 20 data transaksi dilakukan pembentukan itemset. Dari pembentukan kombinasi ini akan dilakukan kombinasi 2 itemset dapat dilihat pada gambar 6.

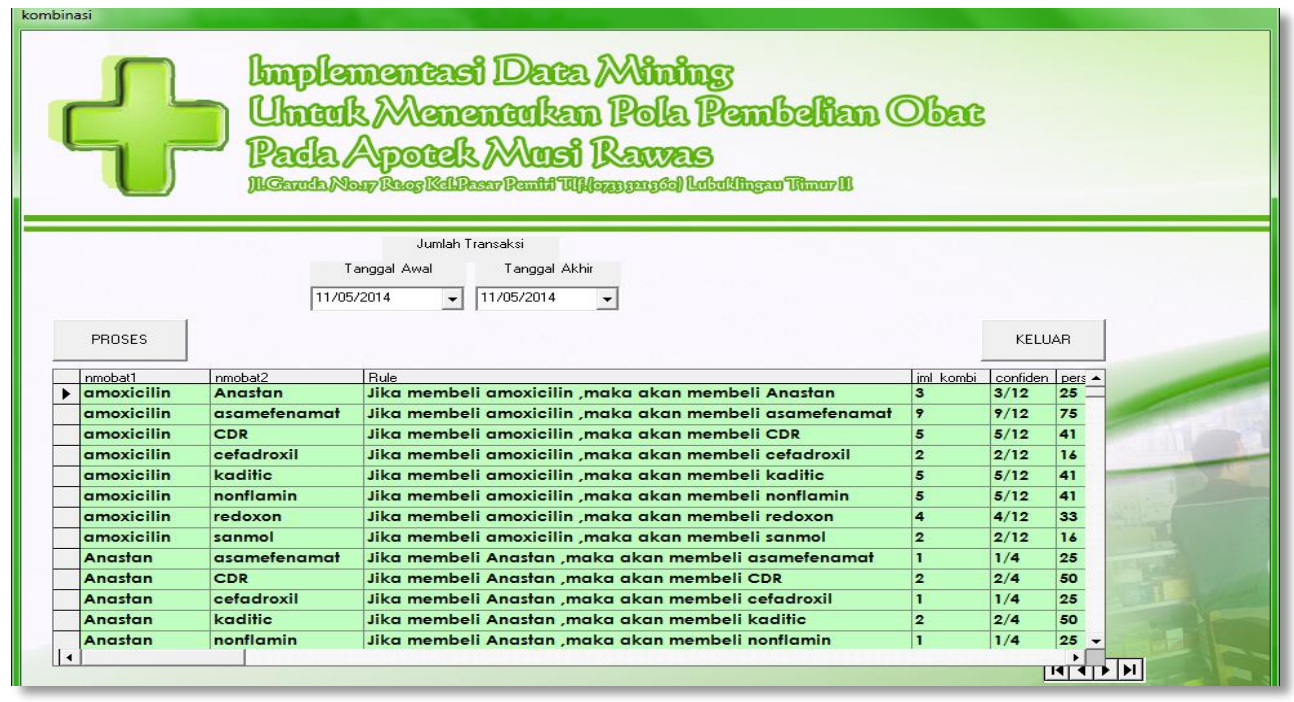

Gambar 5. Proses Perhitungan Data Transaksi

Melihat dari hasil pengujian menggunakan algoritma appriori maka sistem akan diuji dengan minimum support dan minimum confidence yang sama untuk melihat kesesuaian hasil yang ada pada sistem dapat dilihat pada gambar 7. Dimasukan nilai minimum support sebesar 50 
$\%$ dan minimum confidence sebesar $70 \%$ maka dari hasil pembentukan asosiasi pada algoritma apriori dan hasil pembentukan asosiasi pada sistem memperoleh hasil yang sama. Yaitu

1. Jika membeli amoxicilin maka membeli obat asamefenamat dengan confidence $75 \%$

2. Jika Membeli Cefadroxil Maka Membeli Sanmol dengan confidence $77 \%$

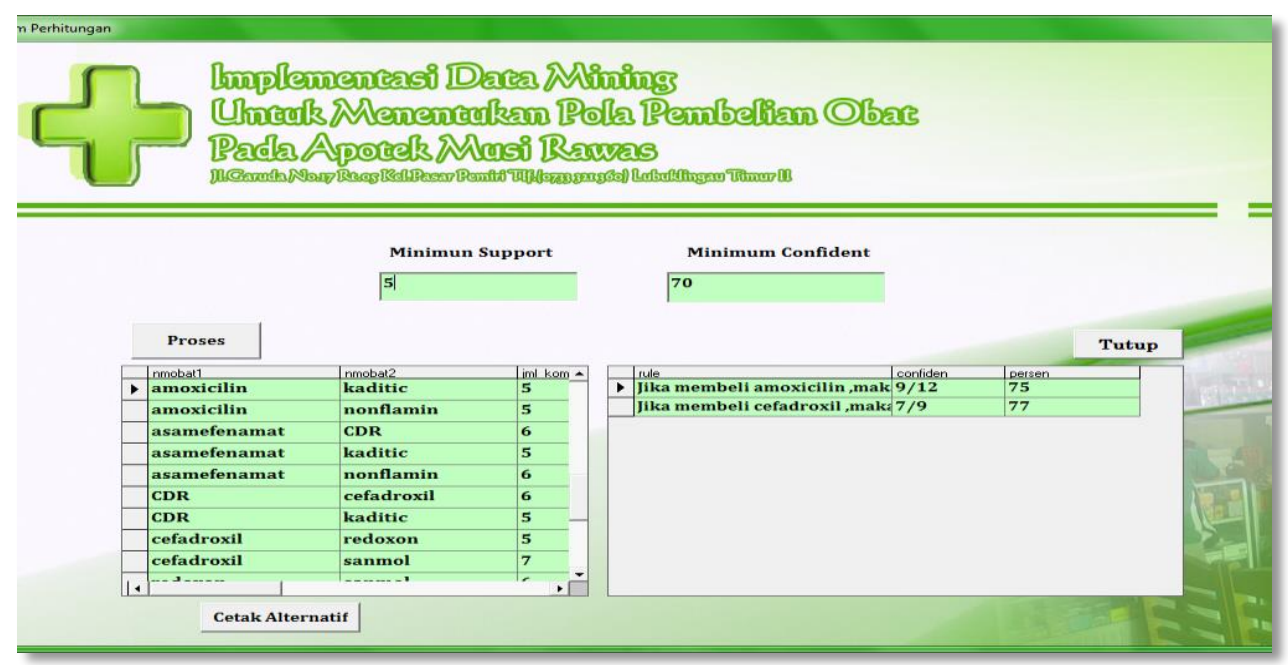

Gambar 6. Hasil Pengujian sistem

\section{HASIL DAN PEMBAHASAN}

Dari proses perhitungan dengan algoritma appriori pada tabel 6 dan dari perhitungan dengan sistem yang dibangun ditentukan nilai minimum support: $50 \%$ dan nilai minimum confidence $70 \%$ maka dihasilkan kecenderungan obat yang dibeli oleh konsumen yaitu:

Tabel 7. Hasil Perhitungan

\begin{tabular}{|l|l|ll|}
\hline No & Teknik Perhitungan & \multicolumn{1}{|c|}{ Hasil } \\
\hline 1 & Perhitungan dengan algoritma Apriori & a. & $\begin{array}{l}\text { Jika membeli amoxicilin maka } \\
\text { membeli obat asamefenamat dengan } \\
\text { confidence } 75 \%\end{array}$ \\
& & b. $\begin{array}{l}\text { Jika Membeli Cefadroxil Maka } \\
\text { Membeli Sanmol dengan confidence } \\
77 \%\end{array}$ \\
\hline 2 & Perhitungan dengan sistem yang dibangun & a. & $\begin{array}{l}\text { Jika membeli amoxicilin maka } \\
\text { membeli obat asamefenamat dengan } \\
\text { confidence 75 \% }\end{array}$ \\
& & bika Membeli Cefadroxil Maka \\
& & Membeli Sanmol dengan confidence \\
& & \\
\hline
\end{tabular}

Dari pengujian menggunakan algoritma appriori dan menggunakan sistem yang dibangun menghasilkan nilai yang sama sesuai dengan nilai minimum support dan minimum confidence yang telah ditentukan. Dari hasil tersebut maka sistem ini dapat membantu pola pembelian obat berdasarkan kecenderungan obat yang dibeli konsumen yang terdiri dari 2 itemset obat, kemudian dari hasil pengujian ini juga dapat membantu pihak karyawan dalam mengatur tata letak obat yang terdiri dari 2 itemset obat secara berdekatan untuk memudahkan karyawan dalam mengetahui keberadaan obat. 


\section{KESIMPULAN}

Proses penentuan pola pembelian obat dapat dilakukan dengan menerapkan data mining dengan metode algoritma appriori. dengan metode tersebut penentuan pola pembelian dapat dilakukan dengan melihat hasil dari kecenderungan konsumen membeli obat berdasarkan kombinasi 2 itemset. Pengetahuan baru yang dapat diperoleh berdasarkan hasil perhitungan algoritma apriori dan sistem yang dibangun dapat dilakukan pengaturan tata letak obat secara berdekatan untuk memudahkan keberadaan obat.

\section{SARAN}

Pada penelitian selanjutnya dapat dikembangkan dengan perhitungan menggunakan algoritma appriori lebih dari 2 itemset. Dapat dilakukan penelitian lebih lanjut dengan memanfaatkan algoritma association data mining lainya seperti Generalized Rule Iduction, Algoritma Hash Based.

\section{DAFTAR PUSTAKA}

[1] Ranjan, J., 2007, Application of Data Mining Technique in Pharmaceutical Industry, Journal of Theoritical and Applied Information Technology, Vol 3, hal $61-67$.

[2] Kusrini, 2007, Penerapan Algoritma Apriori pada Data Mining untuk Mengelompokkan Barang Berdasarkan Kecenderungan Kemunculan Bersama dalam Satu Transaksi, http://dosen.amikom.ac.id/.../Publikasi\%20Apriori-Kusrini_Feb-13_.pdf, diakses 20 Juli 2011.

[3] Kusrini, Luthfi, E. T., 2009, Algoritma Data Mining, Andi Offset, Yogyakarta.

[4] Turban, E., 2005, Decision Suport Systems and Intelligent Systems, Andi Offset, Yogyakarta.

[5] Shalahuddin, Rosa. A.S, 2011, Rekayasa Perangkat Lunak, Informatika, Bandung.

[6] Jogiyanto, 2005, Analisis dan Desain, Andi Offset, Yogyakarta.

[7] Santosa, B., 2007, Data Mining: Teknik Pemanfaatan Data untuk Keperluan Bisnis, Graha Ilmu, Yogyakarta.

[8] Gunadi, G., Sensuse, D., I., 2012, Penerapan Metode Data Mining Market Basket Analysis terhadap data penjualan produk buku dengan menggunakan algoritma Apriori dan Frequent Pattern Growth (FP-Growth), Jurnal TELEMATIKA MKOM, Vol. 4, No. 1, hal 118-132. 